\title{
PELATIHAN PEMBUATAN SOAL INTERAKTIF DENGAN PROGRAM WONDERSHARE QUIZ CREATOR BAGI GURU SEKOLAH DASAR DI KOTA MAGELANG
}

\author{
Arif Wiyat Purnanto dan Astuti Mahardika \\ Prodi PGSD - Fakultas Keguruan dan Ilmu Pendidikan \\ Universitas Muhammadiyah Magelang \\ Jl. Tidar No. 21 Magelang 56126 \\ Email: arifwiyatumm@gmail.com
}

\begin{abstract}
ABSTRAK
Pengabdian ini dilaksanakandi SD Negeri Kedungsari 1 dan diikuti oleh guru di SD Negeri Kedungsari 1 dan SD Negeri Kedungsari 5dalam rangka meningkatkan pemahaman, keterampilan, dan inovasi dalam menyusun soal evaluasi dengan menggunakan program Wondershare Quiz Creator. Dalam pengabdian ini telah dilakukan kegiatan pelatihan untuk membuat soal interaktif dengan tipe pilihan ganda dan isian singkat. Hasil yang diperoleh dari kegiatan pengabdian ini yaitu semua peserta sudah mampu menyusun soal interaktif yang inovatif dan variatif secaa mandiri sehingga akan terbentuk kegiatan evaluasi yang variatif dan menyenangkan. Keuntungan lain yang diperoleh yaitu guru dapat menyusun soal berbasis computer dan soal berbasis kertas dalam satu waktu.
\end{abstract}

Kata Kunci : soal, interaktif, wondershare

\begin{abstract}
This devotion was followed by the teachers of Kedungsari 1 and Kedungsari 5 in pupose of improving the understanding, skills, and innovation in formulating evaluation items using Wondershare Quiz Creator. It included training activities to create interactive questions with multiple choice items and fill in the blank. The results revealed that all participants were able to design interactive items in order to have varied and enjoyable evaluations. Besides, the teachers could design computerbasedand paper-based items at the same time.
\end{abstract}

Keywords : evaluation, interactif, wondershare

\section{PENDAHULUAN}

Guru adalah salah satu profesi yang mulia. Guru sebagai seorang agen pembelajaran dituntut memiliki beberapa kompetensi, diantaranya: kompetensi pedagogik; kompetensi sosial; kompetensi pribadi; dan kompetensi profesional sebagaimana tercantum dalam UU Nomor 14 tahun 2005 pasal 10 ayat (1). Guru merupakan perencana, pemroses, dan evaluator proses pembelajaran di dalam kelas. Sebagai perencana guru harus dapat menyusun segala administrasi dan persiapan yang menunjang kegiatan pembelajaran. Sebagai pemroses kegiatan pembelajaran guru harus dapat menjadi fasilitator yang baik. Sebagai evaluator guru harus dapat melakukan penilaian terhadap seluruh proses 
pembelajaran yang sudah berlangsung baik untuk menilai pencapaian kompetensi peserta didik, bahan penyusunan laporan kemajuan hasil belajar, dan sebagai perbaikan maupun koreksi proses pembelajaran (PP No. 19 Tahun 2005).

Berdasarkan Permendiknas nomor 16 tahun 2007 salah satu kompetensi inti guru adalah menyelenggarakan penilaian dan evaluasi hasil belajar. Penilaian hasil belajar merupakan bagian penting dalam kegiatan pembelajaran. Sistem penilaian yang baik akan mendorong pendidikan untuk menentukan strategi mengajar yang baik dan memotivasi siswa untuk belajar yang lebih baik.Hasil belajar siswa dapat diperoleh melalui hasil tes maupun non tes. Kajian kali ini dibatasi untuk penilaian hasil belajar melalui tes.

Pemerintah telah memberlakukan Kurikulum 2013 melalui pilot project pada sekolah-sekolah tertentu beberapa tahun lalu. Salah satu yang menjadi kendala bagi para guru khususnya sekolah dasar (SD) adalah penilaian. Guru SD umumnya sebagai guru kelas di mana dituntut untuk dapat melakukan pemeblajaran sesuai karakteristik mata pelajaran yang disampaikan, termasuk di dalamnya melakukan penilaian hasil belajar siswa. Hasil observasi menunjukkan bahwa guru masih mengalami kerepotan dalam menyusun, mengevaluasi, bahkan melakukan penilaian. Jenis soal yang digunakan juga masih monoton, seperti menggunakan uraian tes, obyektif tes, isian tes.

Beberapa hal dapat dilakukan untuk memudahkan guru melakukan penilaian hasil belajar siswa. Salah satunya adalah dengan bantuan teknologi komputer yakni penggunaan program atau software tertetentu. Semakin pesatnya kemajuan teknologi memunculkan berbagai jenis aplikasi komputer untuk menunjang proses pembelajaran baik berupa media maupun penilaian pembelajaran. Program komputer Quiz Creator merupakan salah satu program yang dapat diandalkan dalam proses penilaian hasil belajar khususnya tipe tes. Dengan adanya program ini, guru dapat dengan mudah menyusun soal interaktif. Selain itu guru juga dapat dengan mudah mendapatkan skor kemampuan siswa.

Mengingat pentingnya program komputasi ini, untuk itu perlu dilakukan adanya sosialisasi, penyuluhan dan pelatihan penggunaan program komputer Quiz Ceator sebagai salah satu solusi guru khususnya guru Sekolah Dasar dalam melakukan penilaian autentik kepada anak didiknya.

Wondershare Quiz Creatormerupakan perangkat lunak untuk pembuatan soal, kuis atau tes. Tampilan yang sederhana sangat membantu setiap orang dalam penggunaan Wondershare Quiz Creator, sehingga sangat mudah digunakan dan tidak memerlukan kemampuan bahasa pemrograman yang sulit untuk mengoperasikannya.

Dengan Wondershare Quiz Creator, pengguna dapat membuat dan menyusun berbagai bentuk soal yang berbeda, yaitu bentuk soal benar/salah (true/false), pilihan ganda (multiple choices), pilihan respon (multiple response), isian singkat (fill in the blank), menjodohkan (matching), kuis dengan area gambar, bahkan membuat karangan. Dalam soal dapat disisipkan dengan berbagai media pendukung seperti gambar, suara, maupun video. Soal yang di hasilkan dari program ini dapat disimpan dalam format Flash.

Beberapa fasilitas yang tersedia dalam Wondershare Quiz Creator diantaranya yaitu (1) fasilitas umpan balik (feed-back) berdasar atas respon/jawaban dari peserta tes; (2) fasilitas yang menampilkan hasil tes/score dan langkah-langkah yang akan diikuti peserta tes berdasar respon/jawaban yang dimasukkan; (3) fasilitas mengubah teks dan bahasa pada tombol dan label sesuai dengan keinginan pembuat soal; (4) fasilitas memasukkan suara dan warna pada soal sesuai dengan keinginan pembuat soal, dan (5) fasilitas hyperlink; yaitu mengirim hasil/score tes ke email atau LMS; (6) fasilitas pembuatan soal random, (7) fasilitas keamanan dengan User account/password, (8) Fasilitas pengaturan tampilan yang dapat di modifikasi, dll. 
Adapun beberapa syarat yang harus dimiliki komputer ataupun laptop yang akan menggunakan program Wondershare Quiz Creator, yaitu: Microsoft Windows 2000/ XP/2003/Vista/Win7/Win8/Win10, Prosesor minimal $233 \mathrm{MHz}$ Intel Pentium atau AMD K6 processor, Minimal $250 \mathrm{MB}$, Ruang hardisk kosong minimal $50 \mathrm{MB}$.

Wondershare Quiz Creator dapat digunakan sebagai alternatif untuk membuat multimedia pembelajaran interaktif selain menggunakan Macromedia Flash adalah menggunakan Power point. Wondershare Quiz Creator sudah menyediakan tampilan yang user friendly, yaitu mudah dipelajari dan digunakan. Software ini merupakan software lisensi.

Penggunaan Wondershare Quiz Creator dalam pembelajaran akan sangat membantu guru dalam penyusunan soal. Guru akan dimanjakan dengan fitur-fitur yang menarik. Selain itu, media pembelajaran interaktif juga dapat meningkatkan sikapmandiri siswa. Media pembelajaran interaktif merupakan mediapembelajaran yang sangat mudah digunakan dan menghemat waktu,selain itu dapat mendidik siswanya untuk belajar mandiri (Hapsari,2009). Peningkatan motivasi dan kemandirian belajar siswa dilakukandengan menggunakan media pembelajaran interaktif berbasisWondershare Quiz Creator. Media pembelajaran interaktif berbasisWondershare Quiz Creator adalah media pembelajaran interaktifberbentuk soal atau pertanyaan yang disajikan dalam tampilan berupakuis dengan menggunakan aplikasi pembuat kuis interaktif. Kuisinteraktif memungkinkan siswa secara mandiri untuk meningkatkanpemahaman tentang materi pelajaran dengan menekan tombol padatampilan aplikasi (Mazguru, 2010).

Kelebihan lain dari media pembelajaran interaktif berbasis Wondershare Quiz Creator ini yaitu dapat digunakan untuk belajar secara mandiri oleh siswa. Pada setiap materi kompetensi dasar mendeskripsikan jenis produk dalam bursa efek yang menjadi pertanyaan telah disediakan petunjuk yang berkaitan dengan materi dan cara menjawab pertanyaan. Selain itu,guru dan siswa dapat secara langsung mengetahui kemampuan belajarnya dengan adanya hasil atau result yang ditampilkan setelah menyelesaikan semua pertanyaan tersebut. Dengan adanya media pembelajaran interaktif berbasis Wondershare Quiz Creator ini diharapkan dapatmeningkatkanmotivasidankemandirian siswa untuk belajar ekonomikarena materi pelajaran ekonomi disajikan dengan tampilan yang menarik dan memberikan fasilitas pada siswa untuk melakukan kegiatan belajarnya secara mandiri dengan menekan tombol pada tampilan aplikasi.

Persoalan yang dihadapi baik dari sisi produksi maupun dari sisi manajemen selama ini adalah :

1. Kegiatan evaluasi yang dilakukan guru masih bersifat konvensional yang menghabiskan waktu dan biaya

2. Motivasi guru untuk melakukan inovasi dalam kegiatan evaluasi masih kurang

3. Belum adanya sosialisasi/pelatihan terkait dengan program Wondershare Quiz Creator

4. Terbatasnya dana pengembangan pada sekolah mitra

Berdasarkan permasalahan yang dihadapi, maka solusi yang diusulkan untuk menyelesaiakannya yaitu dengan melakukan kegiatan pelatihan pembuatan soal interkatif dengan program Wondershare Quiz Creator. Program ini mampu untuk:

1. Menyusun soal yang lebih interaktif dalam berbagai macam bentuk test dengan menambahkan berbagai media seperti suara, foto, dan video.

2. Membuat soal dalam dua bentuk, yaitu paper based dan computer based.

3. Melakukan evaluasi tanpa perlu melakukan koreksi sehingga langsung diperoleh skor akhir dari masing-masing siswa.

Target luaran program Iptek bagi Masyarakatini mencakup:

1. Peningkatan kualitas evaluasi di lingkungkungan sekolah

2. Peningkatan kreativitas, dan 
keterampilan guru dalam melakukan evaluasi

3. Inovasi dalam pembuatan soal untuk evaluasi.

\section{METODE PELAKSANAAN}

Berdasarkan hasil analisis situasi dan kondisi objektif yang ada pada sekolah mitra, maka didapatkan solusi untuk menyelesaikan masalah. Berikut adalah alur berpikir untuk menyelesaikan masalah di sekolah mitra.

Wondershare Quiz Creator merupakan salah satu program yang dapat digunakan untuk membuat alat evaluasi pembelajaran. Wondershare Quiz Creator dapat digunakan untuk memenuhi kebutuhan pembelajaran baik secara online maupun offline yang dapat dibuat dengan cepat dan mudah. Pengembangan media pembelajaran interaktif dengan Wondershare Quiz Creator dapat mempermudah guru menyiapkan menyusun alat evaluasi pembelajaran. Kegiatan evaluasi akan lebih mudah dilaksanakan karena guru tidak perlu melakukan koreksi hasil pekerjaan siswa. Aplikasi akan secara otomatis menampilkan skor yang diperoleh siswa. Kegiatan evaluasi juga akan akan menarik dan menyenangkan bagi peserta didik karena dengan program soal bisa dilengkapi dengan video, gambar, dan suara.

\section{HASIL DAN PEMBAHASAN}

Kegiatan pelatihan dilaksanakan di salah di SD Negeri Kedungsari 1dengan tujuan untuk meningkatkan kualitas, kreativitas, keterampilan, dan inovasi dalam melaksanakan evaluasi. Pelatihan dilaksanakan selama satu hari, yaitu pada tanggal 15 Oktober 2016durasi sekitar 5 jam efektif untuk melaksanakan pelatihan.

Pemanfaatan program Wondershare untuk membuat soal interaktif dilatar belakangi kondisi obyektif tentang fenomena guru masih menggunakan alat evaluasi konvensional. Motivasi guru untuk melakukan inovasi dalam kegiatan evaluasi juga masih kurang. Dampaknya guru menghabiskan banyak waktu, biaya dan tenaga hanya untuk melaksanakan kegiatan evaluasi. Padahal sejatinya guru potensi untuk membangun sistem evaluasi yang efektif dan efisien.

Kendala yang sering muncul dalam menyusun soal intetaktif adalah sulitnya mengoperasikan aplikasi. Banyak aplikasi menuntut kemampuan yang tinggi dalam mengoperasikannya. Bahasa program yang sulit dimengerti juga menjadi salah satu kendalanya. Ini semua menyebabkan guru enggan untuk menggunakan dan menerapkannya dalam pembelajaran. Oleh karena itu, perlu adanya aplikasi yang ringan, murah, dan mudah untuk digunakan dalam pembelajaran.

Kegiatan pelatihan ini telah dilaksanakan menggunakan tiga metode yaitu presentasi, demonstrasi, dan praktik. Metode presentasi kami gunakan untuk mengenalkan soal interaktif dan software Wondershare Quiz Creator. Metode demonstrasi kami gunakan untuk menjelaskan cara mengoperasikan software Wondershare Quiz Creator. Metode praktik digunakan untuk mengajarkan guru membuat membuat soal interaktif.

Ada tiga langkah yang kami tempuh dalam melaksanakan kegiatan ini yaitu:

1. Persiapan

Tahap ini merupakan tahap awal dari seluruh kegiatan pelatihan. Dalam tahap ini kami melakukan beberapa hal yakni membentuk tim pelaksana, penyusunan modul, penentuan waktu pelaksanaan.

Kemudian panitia mendata kebutuhan kegiatan kegiatan pelatihan seperti lembar presensi, lembar pre-test dan post test, modul, konsumsi, dokumentasi, dan sebagainya.

2. Pelaksanaan Pelatihan

Pelaksanaan pelatihan ini di laksanakan di SD Negeri Kedungari 1. Pada tahapan ini mencakup kegiatan sebagai berikut.

a. Penyampaian Materi

Sebelum kegiatan dimulai, guru diminta untuk mengisi angket terlebih dahulu. Angket ini diberikan dalam rangka untuk mengetahui kemampuan awal atau pemahaman peserta terkait komputer. Angket ini juga bertujuan untuk mengetahui seberapa besar motivasi guru untuk melakukan inovasi dalam 
kegiatan evaluasi pembelajaran.

Berdasarkan angket pra kegiatan yang diisi oleh 17 peserta kegiatan dari SDN Kedungsari 1 dan SDN Kedungsari 5 maka diperoleh data sebagai berikut:

1. Sebanyak $90,44 \%$ hasil angket menunjukkan peserta memiliki motivasi tinggi untuk belajar dan dapat menggunakan aplikasi komputer dalam proses belajar mengajar baik sebagai media maupun evaluasi dalam pembelajaran.

2. Data awal menunjukkan bahwa 74,26

$\%$ yang menggambarkan bahwa peserta terbiasa dengan komputer (computer literate) dalam proses pembelajaran

Berdasarkan data di atas, maka dapat disimpulkan bahwa persentase peserta yang terbiasa menggunakan komputer dalam menunjang kegiatan pembelajaran dikategorikan cukup meskipun belum terlalu tinggi. Namun sebagian besar peserta memiliki motivasi yang sangat tinggi untuk belajar dan dapat menggunakan aplikasi komputer sebagai alat bantu maupun inovasi dalam proses belajar mengajar.

Setelah pengisian angket selesai, kegiatan dilanjutkan dengan memberikan pemahaman awal tentang soal interaktif mulai dari kelebihan, kekurangan, sampai manfaat. Hal ini dilakukan untuk menambah wawasan guru terkait aplikasi apa yang sedang up to date saat ini dan memberikan motivasi kepada guru agar mau belajar dan menerapkan aplikasi ini.

b. Simulasi dan Praktik

Guru diajak untuk mempraktikkan langsung cara membuat soal dengan menggunakan program Wondershare Quiz Creator. Kegiatan ini diawali dengan simulasi yang dilakukan oleh pemateri, kemudian diikuti oleh peserta. Peserta mengikuti setiap instruksi yang diberikan oleh pemateri. Ada dua tipe soal yang dibuat pada pelatihan ini yaitu soal tipe obyektif dan soal tipe isian singkat. Saat menyusun soal objektif, guru diminta untuk membuat dua butir soal terlebih dahulu. Kemudian guru diminta untuk mempublish soal tersebut dalam dua bentuk yaitu paper based dan computer based. Setelah selesai salah satu hasil karya peserta dipresentasikan di depan peserta lain. Kemudian siswa diminta mencoba kembali membuat soal yang lain dengan jumlah butir yang lebih banyak.

Setelah peserta di rasa mampu menyusun soal objektif, peserta diajak membuat soal tipe kedua yaitu isian singkat. Tidak jauh berbeda dengan kegiatan sebelumnya, peserta diminta menyusun soal sesuai instruksi, mempublish, dan mempresentasikan hasil karyanya di depan peserta lain. Setelah kegiatan tersebut selesai, panitia mengecek dan memberikan saran terhadap hasil pekerjaan yang sudah dibuat oleh peserta. Peserta juga diberikan kesempatan untuk tanya jawab dan diskusi terkait dengan program Wondershare. Secara umum guru tidak mengalami kesulitan untuk menggunakan software pada pelatihan ini.

c. Evaluasi

Kegiatan evaluasi dilaksanakan dalam rangka mengetahui tingkat pemahaman peserta terhadap kegiatan yang sudah dilaksanakan. Kegiatan ini dilaksanakn dengan metode angket. Peserta diminta mengisi beberapa angket yang sudah disediakan. Kemudian peserta juga diminta memberikan masukan/saran dari rangkaian kegiatan yang sudah dilaksanakan.

Berdasarkan angket pasca kegiatan yang diisi oleh 15 peserta kegiatan dari SDN Kedungsari 1 dan SDN Kedungsari 5 maka diperoleh data sebagai berikut:

1. Hasil angket menunjukkan angka 90\% mengenai data pendapat peserta bahwa pelatihan memberikan manfaat pada peserta tentang pembuatan soal interaktif untuk evaluasi pembelajaran menggunakan aplikasi Wondershare Quiz Creator

2. Data menunjukkan angka $87.78 \%$ tentang kesan peserta bahwa pelatihan yang dilakukan bersifat menarik sehingga peserta merasa termotivasi dan memiliki keterampilan terkait pembuatan soal interaktif sebagai salah satu inovasi dalam evaluasi pembelajaran. 
Berdasarkan data di atas, maka dapat disimpulkanpelatihan memberikan manfaat pada peserta tentang pembuatan soal interaktif untuk evaluasi pembelajaran menggunakan aplikasi Wondershare Quiz Creator. Selain pelatihan yang dilakukan bersifat menarik sehingga peserta merasa termotivasi dan memiliki keterampilan terkait pembuatan soal interaktif sebagai inovasi evaluasi pembelajaran.

3. Refleksi

Guru di sekolah ini rata-rata mempunyai kemampuan komputerisasi yang cukup untuk mengoperasikan aplikasi Wondershare Quiz Creator dalam penyusunan soal. Karena pada inti dari pelatihan penyusunan soal interaktif adalah membantu guru dalam menyusun, melaksanakan, dan mengoreksi hasil pekerjaan siswa sehingga mampu mempersingkat waktu guru dalam kegiatan evaluasi.

Dari data angket prakegiatan yang diisi 17 peserta menunjukkan keterserapan awal tentang soal interaktif sebagai salah satu jenis evaluasi pembelajaran dapat terlihat seperti diagram pada Gambar 4 di atas. Sedangkan rata-rata persentase keterserapan sebesar 82,01 . Hal ini berarti bahwa wawasan guru dan kemampuan guru dalam menyusun soal interaktif masuk kategori yang kurang baik. Hasil pre-test yang dilakukan menunjukan beberapa hal sebagai berikut.

Pertama, peserta pelatihan sebenarnya memiliki motivasi yang tinggi untuk membuat soal-soal yang variatif dan inovatif. Akan tetapi guru belum banyak mengetahui aplikasi yang dapat digunakan untuk membuat soal yang variatif dan inovatif dalam waktu singkat. Kedua, guru sudah pernah mendapatkan beberapa pelatihan terkait penyusunan soal interaktif, namun penggunaannya yang cukup rumit dan memerlukan koding-koding tertentu membuat guru tidak memanfaatkannya.

Ketiga, keterampilan guru dalam menggunakan komputer menyebabkan guru enggan menggunakan soal inteaktif dikarenakan penyusunan soal interaktif yang cukup memakan waktu.
Padahal dengan soal interaktif kita akan banyak menghemat waktu baik dalam penyusunan, pelaksanaan, sampai proses koreksi. Dari analisis diatas maka dilakukan beberapa penekana dalam materi yang disiapkan sehingga pelatihan bisa berjalan secara efektif dan efisien.

Berdasarkan data angket pascakegiatan yang diisi 15 peserta menunjukkan keterserapan akhir tentang pembuatan soal interaktif menggunakan aplikasi komputer wondershare Quiz Creator sebagai salah satu jenis evaluasi pembelajaran dapat terlihat seperti diagram pada gambar 6 di atas. Rata-rata persentase keterserapan akhir sebesar 86,28 menunjukkan secara rata-rata meningkat apabila dibandingkan dengan katerserapan awal peserta. Ini berarti bahwa pelatihan ini cukup efektif untuk meningkatkan motivasi guru dalam menyusun soal interaktif dan menerapkannya dalam kegiatan pembelajaran.

Dari uraian di atas dapat disimpulkan bahwa kegiatan pelatihanyang telah dilaksanakan berhasil memenuhi tujuannya.Adapun perubahan yang terjadi pada kelompok sasaran kami rangkum sebagai berikut.

\section{Kelompok Sasaran}

Sasaran yaitu seluruh guru di SD Negeri Kedungsari 1 dan SD Negeri Kedungsari 5. Di SD Negeri Kedungsari 1 dan SD Negeri Kedungsari 5 masih banyak guru yang melakukan kegiatan evaluasi berbasis kertas (paper based). Hanya sedikit dari sekian banyak guru yang menggunakan aplikasi pembuatan soal interaktif yang sudah tersedia. Bahkan, beberapa guru belum mengenal aplikasi untuk membuat soal interaktif, sehingga diperlukan pengenalan dan pelatihan bagi guru di SD Negeri Kedungsari 1 dan SD Negeri Kedungsari 5 untuk memanfaatkan aplikasi tersebut.

Keuntungan yang telah diperoleh guruguru di SD Negeri Kedungsari 1 dan SD Negeri Kedungsari 5 adalah:

1. Peningkatan pengetahuan dan
keterampilan dalam menyusun soal 
interaktif yang dapat digunakan untuk meningkatkan efektifitas dan efisiensi dalam proses evaluasi pembelajaran.
2. Peningkatan pengetahuan dan
keterampilan dalam menyusun soal

yang lebih inovatif dan bervariatif.

3. Tumbuhnya semangat untuk menyusun soal secara mandiri dengan memanfaatkan teknologi.

Tabel 1. Kondisi Sebelum dan Sesudah Pelaksanaan Pelatihan

\begin{tabular}{|c|c|c|}
\hline Uraian & Kondisi sebelum kegiatan & Kondisi setelah kegiatan \\
\hline Penyusunan soal & $\begin{array}{l}\text { Guru menyusun soal dengan } \\
\text { menggunakan kertas (paper based) }\end{array}$ & $\begin{array}{l}\text { Guru mampu menyusun soal dengan } \\
\text { komputer (computer based) }\end{array}$ \\
\hline Tipe Soal & $\begin{array}{l}\text { Guru menyusun dengan satu } \\
\text { sampai dua jenis soal }\end{array}$ & $\begin{array}{l}\text { Guru mampu menyusun soal dengan } \\
\text { berbagai jenis mulai dari pilihan ganda, } \\
\text { isian, uraian, menjodohkan, dll. }\end{array}$ \\
\hline Variasi soal & $\begin{array}{l}\text { Satu kelas hanya dibuat satu variasi } \\
\text { soal }\end{array}$ & $\begin{array}{l}\text { Variasi soal sangat banyak sehingga } \\
\text { dapat menghindari kecurangan }\end{array}$ \\
\hline $\begin{array}{l}\text { Pemanfaatan } \\
\text { teknologi }\end{array}$ & $\begin{array}{l}\text { Guru melaksanakan evaluasi } \\
\text { dengan menggandakan soal }\end{array}$ & $\begin{array}{l}\text { Guru melakanakan evaluasi dengan } \\
\text { menggunakan komputer }\end{array}$ \\
\hline
\end{tabular}

\section{KESIMPULAN DAN SARAN}

\section{Kesimpulan}

Dari kegiatan pelatihan pembuatan soal interaktif dengan menggunakan program Wondershare Quiz Creator di SD Negeri Kedungsari 1 dan SD Negeri Kedungsari 5 diperoleh hasil sebagai berikut.

a. Peningkatan pengetahuan dan keterampilan dalam menyusun soal interaktif yang dapat digunakan untuk meningkatkan efektifitas dan efisiensi dalam proses evaluasi pembelajaran baik di SD Negeri Kedungsari 1 maupun di SD Negeri Kedungsari 5.

b. Peningkatan pengetahuan dan keterampilan dalam menyusun soal yang lebih inovatif dan bervariatif sehingga menumbuhkan semangat bagi siswa dalam melaksanakan kegiatan evaluasi.

c. Tumbuhnya semangat untuk menyusun soal secara mandiri dengan memanfaatkan teknologi dan tidak lagi bergantung kepada lembar kerja siswa yang dijual di pasaran.

\section{Saran}

Berangkat dari kesimpulan tersebut, kami mengemukakan beberapa saran sebagai berikut.

a. Peserta pelatihan diharapkan dapat berperan aktif dalam menyebarluaskan ilmu-ilmu yang diperoleh kepada guru-guru lain baik di dalam sekolah maupun di luar sekolah dalam rangka meningkatkan kualitas evaluasi pembelajaran.

b. Masih banyak pihak, terutama sekolah, yang membutuhkan adanya kegiatan pengabdian pada masyarakat oleh perguruan tinggi, untuk membantu guru meningkatkan beragam kompetensi yang dibutuhkan guna meningkatkan kualitas pembelajaran di sekolah. Oleh karena itu, guru-guru di sekolah dasar lebih diperhatikan/diprioritaskan dalam hal pelatihan dan pendampingan dalam berbagai upaya peningkatan kualitas pembelajaran yang dilakukan perguruan tinggi.

\section{Persantunan}

Ucapan terimakasih disampaikan kepada :

1. Lembaga Penelitian Pengembangan dan Pengabdian kepada Masyarakat (LP3M) Universitas Muhammadiyah Magelang yang telah memberikan dukungan moril dan finansiil dalam pelaksanaan Pengabdian di SD Negeri Kedungsari 1 
dan SD Negeri Kedungsari 5 ini.

2. Ibu Kepala Sekolah dan bapak ibu guru

SD Negeri Kedungsari 1 dan SD Negeri

Kedungsari 5.

\section{DAFTAR PUSTAKA}

Arikunto, S. 2010. Dasar-Dasar Evaluasi Pendidikan (Edisi Revisi). Jakarta: Bumi Aksara

Badudu. 2001. Kamus Besar Bahasa Indonesia.Jakarta : Pustaka Harapan

Permendikbud Nomor 104 Tahun 2014 tentang Penilaian Hasil Belajar oleh Pendidik pada Pendidikan Dasar dan Pendidikan Menengah

Permendikbud Nomor 16 Tahun 2007 tentang Standar Kualifikasi Akademik dan Kompetensi Guru

Purwanto, S. 2005. Penggunaan Model Assesmen Portofolio dalam Penilaian Proses dan Hasil Belajar Matematika Siswa SMU. Vol 3. No. 2.

Rudianto, Onny. 2013. Membuat Soal Interaktifdenganuntuk Bahan Ajar Berbasis Web. diunduh dari www.onnyrudianto.wordpress.com pada tanggal 29 April 2016

Undang-Undang Nomor 14 Tahun 2005 Tentang Guru dan Dosen

Widoyoko, E. P. 2014. Evaluasi Program Pembelajaran. Yogyakarta: Pustaka Pelajar. 